\title{
RESEARCH OF FOREIGN INVESTORS' OPINIONS ON THE QUALITY OF WORKFORCE EDUCATION AND PROFESSIONAL IMPROVEMENT IN THE AUTONOMOUS PROVINCE OF VOJVODINA
}

\author{
Biljana Stankov* \\ Novi Sad School of Business, Novi Sad, Republic of Serbia \\ Jelena Damnjanović \\ Novi Sad School of Business, Novi Sad, Republic of Serbia \\ Milijana Roganović \\ Novi Sad School of Business, Novi Sad, Republic of Serbia
}

\begin{abstract}
One of the measures for the promotion of economic development, which has been intensively applied in the region of the Autonomous Province of Vojvodina in recent years, refers to stimulation of FDI inflows. AP Vojvodina is considered to be a very attractive investment location, which especially stands out for its favorable geographical location, liberal foreign investment laws and labor laws, highly educated and skilled workforce that can be engaged at low costs, as well as the tax incentives and numerous financial incentives available interested foreign investors. Reviewing the scientific and professional literature, it can be concluded that the value of human capital has very often been investigated as a determinant of FDI inflows, and mainly expressed through the level and quality of education and skills of workers. By conducting a survey of foreign investors operating in the free investment zones of AP Vojvodina, it was concluded that the respondents were satisfied with the quality of education and professional development of the workforce. By analyzing the obtained research results, the authors of this empirical study, while respecting the opinions of other authors, simultaneously provided scientific contributions to the subject area, as well as practical contributions in the form of concrete recommendations for public policy makers, primarily foreign investment policy and education policy in the territory of AP Vojvodina.
\end{abstract}

Key words: foreign direct investments (FDI), foreign investors, Autonomous Province of Vojvodina, workforce, quality of education, professional development

JEL Classification: F21, E22, E24

*bilja.1.stankov@gmail.com 


\section{Biljana Stankov, Jelena Damnjanović, Milijana Roganović | 53 \\ ISTRAŽIVANJE MIŠLJENJA STRANIH \\ INVESTITORA O KVALITETU OBRAZOVANJA I \\ STRUČNOG USAVRŠAVANJA RADNE SNAGE U AP \\ VOJVODINI}

Sažetak: Jedna od mera za unapređenje privrednog razvoja, koja se poslednjih godina intenzivno primenjuje u regionu Autonomne Pokrajine Vojvodine, odnosi se na podsticanje priliva SDI. AP Vojvodina se smatra veoma atraktivnom investicionom lokacijom, koja se posebno ističe povoljnom geografskom lokacijom, liberalnim zakonima o stranom investiranju i zakonom o radu, visokoobrazovanom $i$ stručnom radnom snagom koja se može angažovati uz niske troškove, kao i poreskim $i$ brojnim finansijskim podsticajima koji su na raspolaganju zainteresovanim stranim investitorima. Pregledom naučne i stručne literature može se zaključiti da je vrednost ljudskog kapitala veoma često bila istraživana kao determinanta priliva SDI, a uglavnom iskazivana putem stepena $i$ kvaliteta obrazovanja i stručnosti radnika. Sprovođenjem anketnog ispitivanja stranih investitora koji posluju $u$ slobodnim investicionim zonama AP Vojvodine, došlo se do zaključka da su ispitanici zadovoljni kvalitetom obrazovanja i stručnog usavršavanja radne snage. Analizom dobijenih istraživačkih rezultata, autori ove empirijske studije su, uz uvažavanje mišljenja drugih autora, istovremeno pružili naučni doprinos predmetnoj oblasti, kao i praktični doprinos u vidu konkretnih preporuka za kreatore javnih politika, pre svega politike stranog investiranja $i$ politike obrazovanja na teritoriji AP Vojvodine.

Ključne reči: strane direktne investicije (SDI), strani investitori, Autonomna pokrajina Vojvodina, radna snaga, kvalitet obrazovanja, stručno usavršavanje

\section{INTRODUCTION}

Professional and scientific literature abound in studies on foreign direct investments (FDI), especially those that research the determinants of the FDI inflows in the host countries. At the end of XX and the beginning of XXI centuries, FDI became one of the most attractive forms of foreign investment in this area, which encouraged especially the countries and regions in development to compete for attracting it. Hallward-Driemeier (2003) states that it was precisely in that period that a great number of developing countries competed in hopes of becoming hosts to the multinational companies. This is confirmed by the World Bank's data that show that, on a global level, FDI inflows increased from $19 \%$ in 2009 to $52 \%$ in 2010, and that even the half of the 20 leading recipients of these investments were developing countries. During 2015, in the developing countries, FDI inflows had reached the highest value compared to the previous years $(\$ 765$ billions) and became $9 \%$ bigger compared to movements in 2014. During the 
54 | RESEARCH OF FOREIGN INVESTORS' OPINIONS ON THE QUALITY OF WORKFORCE EDUCATION AND PROFESSIONAL IMPROVEMENT IN THE AUTONOMOUS PROVINCE OF VOJVODINA

said period, the developing countries and regions, among which are the Republic of Serbia and AP Vojvodina, became the world's biggest FDI receivers and hosts of a great number of foreign investors. The attractiveness of these investment destinations, among other things, is based on the inability to satisfy the increasing national needs for the investment in key economic areas with their own resources. National savings do not provide enough means that would satisfy the investment needs of a country or a region in development, so the solution is being looked for the intensifying of the FDI inflows.

Through researching different author's views on the benefits from FDI, we can see that the common elements that stand out are the advantages of securing needed financial resources and the advanced technologies, access to different markets, skills innovation and the technique of managing and implementing positive business practices, especially when it comes to the environmental protection and the respect for environmental standards. Government representatives of the hosting countries support this form of investment because, among other things, the obligations based on FDI can be serviced more easily compared to the obligations brought by loans or portfolio investments.

FDI often represents the driving force of the growth in the developing countries. It is done by increasing capital supplies, decreasing unemployment and bringing modern management skills and new technologies. The said contributions are especially important for the developing countries where GDP and state savings are on a significantly low level, which is why it is important to encourage inflows of capital from the external sources in order to increase the total investments and to speed up the economic growth. Thanks to the many advantages such as: favorable geographical and strategic position, the abundance of natural resources, the liberal labor law, benefits when employing and firing workers, friendly FDI laws, low startup costs, benefits that stem from signed multilateral and bilateral agreements on free trade, the candidate status for the European Union and the variety of the investment incentives, the Republic of Serbia and its economically and culturally most developed region, AP Vojvodina, became a very attractive investment location in the past decades.

The research problem within this empirical study is about the quality of human capital as the source for the attractiveness of AP Vojvodina as the investment destination and the particularity of the motives given to the foreign investors for investing in this region. The subject of the research is focused on the foreign investors who do business in the free investment zones of AP Vojvodina, as well as the analysis of their opinions on the 
Biljana Stankov, Jelena Damnjanović, Milijana Roganović | 55 quality of education and the professional training of the workforce. One of the key reasons for creating free investment zones is the increase of the national and regional employment, which motivated the authors of this empirical study to dedicate themselves to the research of the aforementioned issues and to reach relevant and well-founded conclusions. According to the latest data of Free Zones Administration, in the Republic of Serbia there are currently 14 free zones, 4 of them being on the territory of AP Vojvodina (Novi Sad, Zrenjanin, Subotica i Apatin). Between 2012 and 2017 the number of business entities that operate in the free zones, increased from 173 to 221 , and one quarter of the companies was owned precisely by the foreign investors. During the creation of this empirical study, the authors' goal was to define the appropriate recommendations for the directing the future development of the education system, based on research results, as well as to adjust the types and quality of education to the labor market needs, to decrease the unemployment and to improve the existing qualification structure of the workers in accordance with the needs of the foreign investors as the employers. The authors want, besides the aforementioned, to suggest the measures of active employment politics that would bring the improvement in the labor market, especially in terms of decreasing the difference between needed and available qualified personnel on the territory of AP Vojvodina. It is expected that the results of this research will also find broader application in creating employment measures and education politics in AP Vojvodina, but also to serve as the quality basis for future researches of the authors and, at the same time, to enrich the professional and scientific literature in the subject area.

The first part of these study will be specially focused on considering views of different authors on the education and the workforce training as one of the key determinants of FDI inflows, furthermore comparing it with the research results of the previous empirical studies. The second part encompasses the methodological frame of research and is focused on defining the research hypothesis, the research causes and the timeframe of the research, as well as processing and analysis of the gathered data. The thirds part will present the research results, conclusions, define professional and scientific contribution of this study and define the key recommendation for the target groups.

\section{LITERATURE REVIEW ABOUT LABOUR EDUCATION AS FDI DETERMINANT}

In the last years, both the researchers as well as the creators of public policies show the concern when it comes to the increasing globalization, such as the one manifested through FDI, but also through the international trade that conditions the creation of the dramatic changes in the search for workers in the developed world. Improvement of education and the global SCHOOL OF BUSINESS, 2/2019, 52-77 
56 | RESEARCH OF FOREIGN INVESTORS' OPINIONS ON THE QUALITY OF WORKFORCE EDUCATION AND PROFESSIONAL IMPROVEMENT IN THE AUTONOMOUS PROVINCE OF VOJVODINA

increase of the value of human capital is key for attracting and adoption of new technologies, as well as for generating long term, sustainable growth. Raziny, Rubinsteinzand and Sadkax (2004) emphasise that a certain country or a region can influence the increase of possibility of being "liked" by foreign investors if it improves its own education system.

Foreign investors in developing countries are often motivated by low workforce costs and liberal labor laws that enable them to easily employ and fire workers, yet in the past decades it is the qualification of the workforce that is emphasized as one of the leading determinants. The majority of foreign investments realized in the developing countries from the late ' 80 s to the early ' 90 s, belong to the group of efficiency-seeking investments, which is why it was expected that a highly qualified workforce should be of crucial importance (Miyamoto, 2003).

Nunnenkamp and Spatz (2003) and Barro and Lee (2000) tested the importance of the average study years of the total population when they researched the determinants of FDI. They showed that there was an increasing trend of emphasizing the importance of education from the late ' 80 s until the early ' 90 s.

However, in the host countries of the foreign investors there is often the issue of either nonexistent or insufficient offer of the adequately qualified workforce (Szanyi, 2003). Researching the ways FDI influences labor movements, Slaughter (2002) emphasises that these investments are showing a positive influence both on the supply and on the demand of the qualified workers in the host country. Moreover, Becker and Muendler (2008) say that FDI often influences employee retention in the host country, especially when it comes to the highly educated workforce. With the arrival of the foreign company there is an increase of the search for the qualified workers within a certain economic branch or a region which leads to the increase of the earning dispersion. Driffield and Taylor (2000) note that one of the key influences of FDI can be seen in the increase of the differences in the level of earnings.

In scientific and professional literature there is a great number of direct connections between FDI inflows and higher education. From time to time, foreign companies provide scholarships for highschool and university students, and sponsor the programs of formal education of individual workers in the host country, but are also active in encouraging the improvement of Universities and other similar institutions in various ways. Foreign companies have very attractive employment offers for the highly qualified graduate students in the areas of natural sciences and engineering, which can be additional encouragement for the talented students for SCHOOL OF BUSINESS, 2/2019, 52-77 
Biljana Stankov, Jelena Damnjanović, Milijana Roganović | 57 graduating from higher education schools. The search done by the foreign companies is, first and foremost, focused on qualified workers that can especially encourage the host country to invest in higher education. Many foreign companies in AP Vojvodina provide their employees different training programs, where the scope and the type of the program has to do with the characteristics of the economic branch, the ways the foreign capital is entering the host country, the size and timeframe of the investment, type of business activities and local conditions.

Zhang-Markusen (1999) claim that the multinational companies would not choose to invest in a certain country even if the wages of the unqualified workforce are extremely low, but that they will start investing only when the country has qualified workforce.

Many authors found that there is a complementary connection between FDI inflows and the education degree of the workforce (Xu 2000; Zhang 2001; Durham 2004; Chang, Kaltani and Loayza, 2009; Wang and Wong 2009). Akin and Vlad (2001) researched the importance of the education quality and its role and influence on the relationship between FDI and economic growth in the host country. Researches can be found that are mostly oriented to the quantity of education, and that do not take into account the differences of education quality on the whole territory of the host country.

Moreover, there are those researches that conclude that one year of education does not condition the creation of the same quantity of acquired knowledge in different countries. Hanushek and Wößmann (2007) emphasise that most studies deal with the number of study years, disregarding the qualitative differences in the acquired knowledge. Therefore, certain authors conclude that the quality of education, measured by cognitive abilities of the population, encourages FDI inflows which positively influences the economic growth (Hanushek and Kimko, 2000, Boswort and Collins, 2003). The results of many research studies encourage the importance of education quality, but also state and for the improvement of the education quality it is not often needed to increase the quantity of education in order for FDI inflows to positively influence the economic growth in the host country ((Borensztein, De Gregorio and Lee, 1998).

Feenstra and Hanson (1997), as well as Aghion and Howitt (1998) concluded that the education and the qualification of workers in the host country represent very important FDI determinants that influence the simplest technology transfer. There are numerous empirical studies that emphasise that it is precisely the availability of the workforce who have certain skills a very important FDI determinant in host countries (Noorbakhsh, Paloni and Youssef (2001); Nunnenkamp and Spatz 2002). 
58 I RESEARCH OF FOREIGN INVESTORS' OPINIONS ON THE QUALITY OF WORKFORCE EDUCATION AND PROFESSIONAL IMPROVEMENT IN THE AUTONOMOUS PROVINCE OF VOJVODINA

The lack of the quality education and the qualified workers can discourage foreign investors and jeopardize transitory process in host countries.

Investing in education encourages the attraction of FDI, especially in those countries and regions where schools and education has been often neglected and/or was not adequate from the perspective of the foreign investor. The results of the empirical study of Akin and Vlad (2011) who researched the relationship between education and FDI, show the existence of strong empirical proofs that further show that investing in education was almost always connected with the rise of net FDI inflows in the developing countries of Latin America. The research was done based on the sample of 21 countries during the period from 1984 to 2008 and it was established that, not only that there was a statistically significant influence, but that there was also a quantitatively important positive influence of the investment in education on FDI inflows in the said countries. On the other hand, Harms and Lutz (2006) concluded that from 1988 to 1999 the total investment in education on its own did not show a significantly important influence on FDI inflows in the cases of 92 developing countries that were host countries in that period.

During the ' $50 \mathrm{~s}$ and ' 60 s, the first studies were created on FDI determinants that were mostly qualitative, because of the very modest means of doing a more extensive statistical analysis and were often limited in terms of the data availability on FDI movements. Dunning (1993) says that there are many applied quantitative and qualitative methods in researching FDI inflows determinants which can be difficult to compare. Schneider and Frey (1985) are the authors of the estimated empirical study on FDI determinants, whose results are often cited in the professional literature. They were one of the first to classify the determinants of the FDI inflows, sorting them in two groups:

- Political determinants (first and foremost political instability)

- Economic determinants (rise of GDP, inflation, balance of payment stability, expenses and the skills of the workforce).

Their research included 54 developing countries. By applying the analysis of panel series it was established that during 1976, 1979 and 1980 FDI inflows was positively influenced by political stability, skills of the workforce, the market size, low inflation and low workforce costs.

Many authors used the analysis of the panel series to research the influence of the value of human capital of FDI movements in host countries. They also took into account the level of education, qualification and workforce expertise. The value of human capital, besides the aforementioned, was the 
Biljana Stankov, Jelena Damnjanović, Milijana Roganović | 59 independent variable in the empirical studies of the following authors: Abbas and El Mosallamy (2016); Baez (2014); Lansbury, Pain and Smidkova (1996); Nunes, Oscategui and Peschiera (2006); Pravakar (2006); Ranjan and Agarwal (2011) and Soumia and Tchana Tchana (2011).

While working on the determinants of FDI inflows in the developing countries, Nunnenkamp (2002) applied, as one of the independent variables, basic and other education levels, while education in the general sense was researched by Chen and Kwan (2000). Secondary education of the workforce was one of the independent research variables in the empirical studies of Sakali (2013), Gorbunova, Infante and Smirnova (2012) and Mahmood, Ehsanullah and Ahmed (2011). Sakali (2013), apart from the secondary education, also researched the influence of higher education as a key indicator of the workforce quality on FDI inflows in Bulgaria. The skills of the workforce in the transitioning and developing countries, were the independent variable in the empirical studies of Kinoshita and Campos (2002) and Schneider and Frey (1985).

Akin and Vlad (2011) found, by using the panel data analysis, that among the variables that have to do with the education, only higher education stands out as a statistically significant variable that positively influences FDI. The results of their research show that higher and superior education is more relevant in terms of primary and secondary education and that the human capital represents a very important determinant of FDI inflows.

However, most authors that worked on the determinants of FDI inflows in host countries found the existence of the statistically important positive influence of the education as an independent research variable. Agiomirgianakis, Asteriou and Papathoma (2003) were working on the determinants of FDI inflows in 20 OECD countries from 1975 to 1997. They concluded that, among other variables, the costs and the skills of the workforce were statistically significant variables with different direction of influence. Height costs of the workforce negatively influences FDI in the researched countries, while the skills of the workforce show a positive influence. Anastassopoulos (2007) sampled 15 countries from 2003 to 2006 and got the results that showed that there was a statistical importance of many independent variables. Moreover, the positive influence on FDI was also determined in the case of the expertise and the productivity of the workforce. Baez (2014) did a research on a combined sample of 65 developing countries and developed countries. He found that during the period from 1996 to 2009 the independent variables that deal with the size and the market openness, as well as the value of human capital, had a positive influence of FDI inflows in the researched countries. Gorbunova, Infante and Smirnova (2012) paid special attention on determining FDI 
60 | RESEARCH OF FOREIGN INVESTORS' OPINIONS ON THE QUALITY OF WORKFORCE EDUCATION AND PROFESSIONAL IMPROVEMENT IN THE AUTONOMOUS PROVINCE OF VOJVODINA

inflows in 26 countries in transition precisely during the period when the transitory reforms had been most intense (1994-2002). During the transition period, among other variables, the quality of education in high schools positively influenced the incitement of FDI inflows. Kinoshita and Campos (2002) researched 25 developing countries in '90s and came to the conclusion that the expertise of the highly educated workforce positively influenced FDI inflows. Mahmood, Ehsanullah and Ahmed (2011) researched mostly macroeconomic variables as the potential determinants of FDI inflows in Pakistan during a very long research period (from 1975 to 2005). They came to the conclusion that the influence of the gross rate on the enrollment in high schools, size and growth of the market was significant and positive. Nunnenkamp (2002) did the analysis of panel data series on the sample of 28 developing countries, that are not in Europe, in the period from 1987 to 2000. In order to discover the key determinants of FDI inflows in these countries, he tested the importance of a very large number of independent variables, and the results show that the influence of the market size and the total number of the study years (primary, secondary and higher education) on FDI inflows in the researched countries was positive and statistically significant. Sakali (2013) researched the determinants of FDI inflows in Bulgaria in the period from 1998 to 2008. The dependant variable was the bilateral FDI flows from 12 investing countries to Bulgaria as the host country. The author, among other things, concluded that the influence of workforce quality on FDI inflows was positive and statistically significant, and it was defined by the quality of secondary and higher education in Bulgaria. Soumare and Tchana Tchana (2011) did an empirical research by using the analysis of panel data series, 2SLS and 3SLS models (Two-Stage Least Squares and Three-Stage Least Squares) on the sample of 29 countries in the making of in development that are in Africa, Asia, Eastern Europe and Latin America. The research period encompassed the years from 1994 to 2006. The results of this research showed that the infrastructure, education of the workforce, the development of the financial market, the size and openness of the market of the researched countries are statistically significant and positively influence FDI inflows.

Smaller number of authors observe in their research that the value of the human capital, shown through the education of the workforce, is not a statistically significant variable and does not influence FDI inflows in the researched host countries. Chen and Kwan (2000) found that during the period between 1985 and 1995 the education of the workforce in China did not significantly influence foreign investors to choose one of the researched Chinese regions as their investment location. Popocivi and Calin (2015) used the analysis of the panel series examined the existence of the influence of the 
Biljana Stankov, Jelena Damnjanović, Milijana Roganović | 61 pillars of competitiveness on FDI inflows in $10 \mathrm{CEE}$ region countries and EU members in 2013. It was concluded that the influence of the macroeconomic stability, higher education, improvement and financial development on FDI inflows in these countries was not statistically significant. Ranjan and Agarwal (2011) wanted to find out which key factors influence foreign investors to choose one of the BRICS countries as the investment location. They determined that, besides other variables, the value of human capital is not a statistically significant variable, while the costs of the workforce are stimulating for the foreign investors. In the literature there are also authors such as Blomstrom, Lipsey and Zeyan (1992) who concluded that there is no positive influence on the education on FDI inflows by observing the variables that condition the growth of developing countries. On the other hand, Hanson (1996), discovers that literacy rate of the adult population is not a statistically significant FDI determinant, while Narula (1996) concludes that higher education also does not show statistical significance and cannot explain the movements of FDI inflows.

Rare are the studies such as Abbas and El Mosallamy (2016) who, by researching the determinants of FDI inflows in developing countries that belong to MENA region, in the period from 2006 to 2013 determined that the value of human capital showed negative, statistically significant influence on FDI inflows.

\section{RESEARCH METHODOLOGY}

\subsection{RESEARCH SAMPLE}

The initial research sample encompassed 22 examinees, that is, the companies that are owned by foreign investors, and are situated in the free investment zones of AP Vojvodina. It was determined through the direct contact with the examinees that two companies in the free zone of Novi Sad stopped working, so the research was done on 20 examinees. The questionnaires were delivered by mail and email, with 10 companies being on the addresses in the free zone of Novi Sad, 3 companies in Zrenjanin free zone, 5 companies in Subotica free zone and 2 companies in Apatin free zone. The examinees were asked to fill in the questionnaire anonymously and to return them to the researchers' address through mail (delivery fees were paid by the researcher). From September till the end of December 2019, 18 filled out questionnaires were received which were included in further processing.

\subsection{DATA COLLECTING}

Considering the frequent and efficient application of the method of examination in the researches of different aspects of social reality, the 
62 I RESEARCH OF FOREIGN INVESTORS' OPINIONS ON THE QUALITY OF WORKFORCE EDUCATION AND PROFESSIONAL IMPROVEMENT IN THE AUTONOMOUS PROVINCE OF VOJVODINA

authors of this study chose to gather the necessary research data with a questionnaire. Foreign investors who operate in the free investment zones of AP Vojvodina were asked, through written statements, to give their stances and opinions on different aspects related to the workforce.

This empirical study processed the answers to closed questions and the questions that were given in the form of Likert scale, which relate to the education quality and the level and quality of professional training of the engaged workforce.

The evaluation of the quality of the educational system of the Republic of Serbia were researched, as well as the quality of the particular segments of education. The examinees were required to express their stance by giving 1 to 5 (1 - poor; 2 - fair; 3 - good; 4 - very good; 5 - excellent) on the following variables:

- Quality of education system of the Republic of Serbia.

- Quality of education in primary schools.

- Quality of education in secondary vocational schools (three years duration).

- Quality of education in secondary vocational schools (four years duration).

- Quality of education in high schools.

- Quality of education in higher schools of vocational studies.

- Quality of education in faculties.

- Quality of education in business schools (higher education).

- Quality of education in mathematical sciences (higher education).

- Quality of education in technical sciences (higher education).

Besides the aforementioned, the important segment of this research also referred to the answers related to the professional training of workers, organization of professional training for students and the cooperation of the examinees at the higher education institutions and the development research centers.

\subsection{RESEARCH HYPOTHESES}

Considering the research subject within this empirical study, as well as based on the research goals that the authors strive for, general, specific and measurable research hypotheses were defined. They are showen at Table 1. 
Table 1

General, specific and measurable research hypotheses

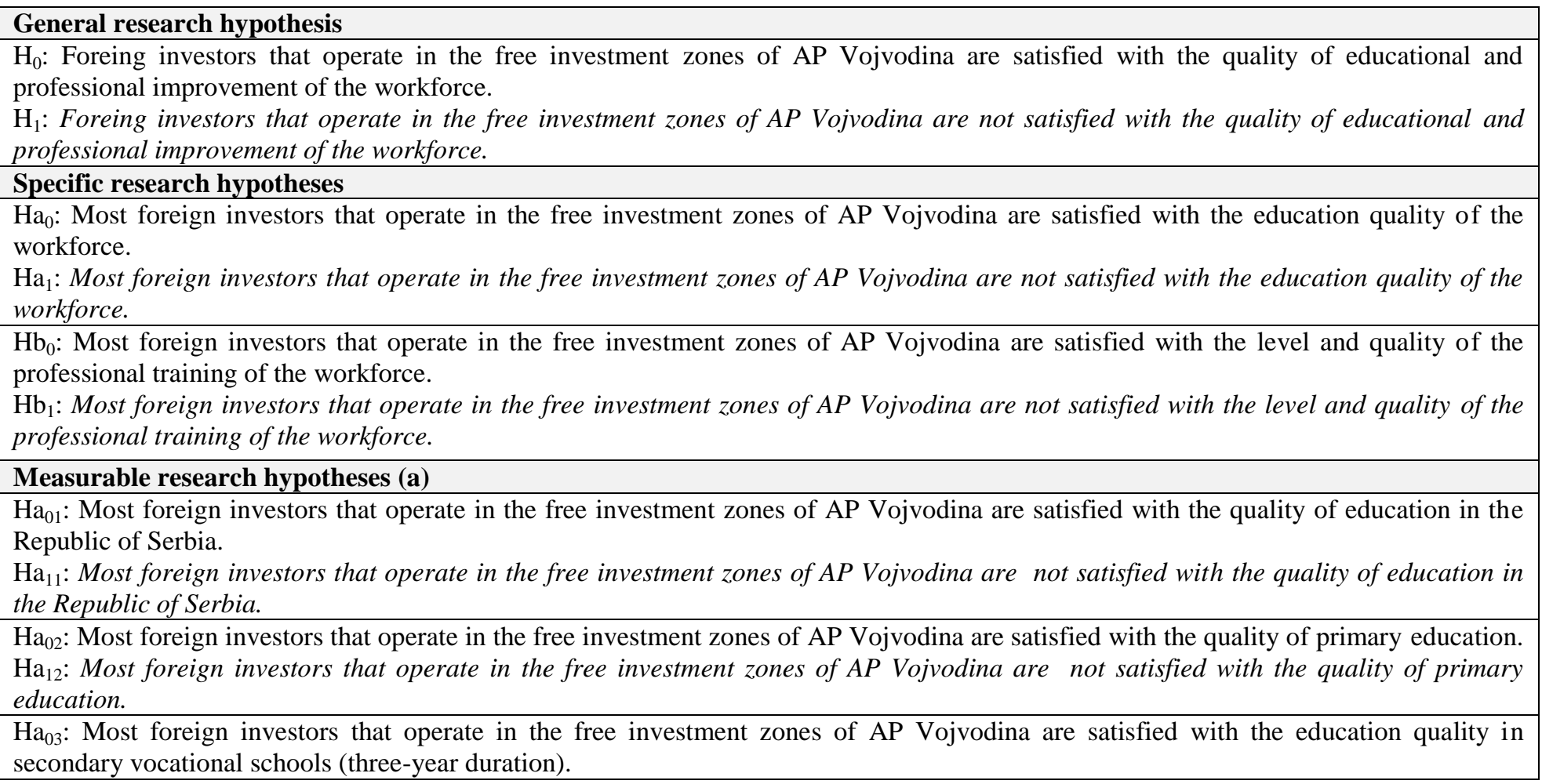


64 | RESEARCH OF FOREIGN INVESTORS' OPINIONS ON THE QUALITY OF WORKFORCE EDUCATION AND PROFESSIONAL IMPROVEMENT IN THE AUTONOMOUS PROVINCE OF VOJVODINA

$\mathrm{Ha}_{13}$ : Most foreign investors that operate in the free investment zones of AP Vojvodina are not satisfied with the education quality in secondary vocational schools (three-year duration).

$\mathrm{Ha}_{04}$ : Most foreign investors that operate in the free investment zones of AP Vojvodina are satisfied with the education quality in secondary vocational schools (four-years duration).

$\mathrm{Ha}_{14}$ : Most foreign investors that operate in the free investment zones of AP Vojvodina are not satisfied with the education quality in secondary vocational schools (four-years duration)

$\mathrm{Ha}_{05}$ : Foreign investors that operate in the free investment zones in AP Vojvodina are satisfied with the education quality in high schools.

$\mathrm{Ha}_{15}$ : Most foreign investors that operate in the free investment zones in AP Vojvodina are not satisfied with the education quality in high schools.

$\mathrm{Ha}_{06}$ : Foreign investors that operate in the free investment zones in AP Vojvodina are satisfied with the education quality in higher vocational schools.

$\mathrm{Ha}_{16}$ : Most foreign investors that operate in the free investment zones in AP Vojvodina are not satisfied with the education quality in higher vocational schools.

$\mathrm{Ha}_{07}$ : Foreign investors that operate in the free investment zones in AP Vojvodina are satisfied with the education quality in faculties.

$\mathrm{Ha}_{17}$ : Most foreign investors that operate in the free investment zones in AP Vojvodina are not satisfied with the education quality in faculties.

$\mathrm{Ha}_{08}$ : Foreign investors that operate in the free investment zones in AP Vojvodina are satisfied with the education quality in business schools (higher education).

$\mathrm{Ha}_{18}$ : Most foreign investors that operate in the free investment zones in AP Vojvodina are not satisfied with the education quality in business schools (higher education).

$\mathrm{Ha}_{09}$ : Foreign investors that operate in the free investment zones in AP Vojvodina are satisfied with the quality of education in the area of mathematical sciences (higher education).

$\mathrm{Ha}_{19}$ : Most foreign investors that operate in the free investment zones in AP Vojvodina are not satisfied with the quality of education in the area of mathematical sciences (higher education).

$\mathrm{Ha}_{010}$ : Foreign investors that operate in the free investment zones in AP Vojvodina are satisfied with the quality of education in the area of technical sciences (higher education).

$\mathrm{Ha}_{110}$ : Most foreign investors that operate in the free investment zones in AP Vojvodina are not satisfied with the quality of education in the area of technical sciences (higher education). 


\section{Measurable research hypotheses (b)}

$\mathrm{Hb}_{01}$ : Foreign investors that operate in the free investment zones in AP Vojvodina provided the attendance of certain professional training programs for certain workers.

$\mathrm{Hb}_{11}$ : Foreign investors that operate in the free investment zones in AP Vojvodina did not provide the attendance of certain professional training programs for certain workers.

$\mathrm{Hb}_{02}$ : Most foreign investors that operate in the free investment zones in AP Vojvodina internally organized certain professional training programs for their workers.

$\mathrm{Hb}_{12}$ : Most foreign investors that operate in the free investment zones in AP Vojvodina did not internally organized certain professional training programs for their workers.

$\mathrm{Hb}_{03}$ : Most foreign investors that operate in the free investment zones in AP Vojvodina admitted pupils and/or students for professional practice or training.

$\mathrm{Hb}_{13}$ : Most foreign investors that operate in the free investment zones in AP Vojvodina did not admit pupils and/or students for professional practice or training.

$\mathrm{Hb}_{04}$ : Most foreign investors that operate in the free investment zones in AP Vojvodina have at their disposal adeequate centraining center for their workers on the local level.

$\mathrm{Hb}_{14}$ : Most foreign investors that operate in the free investment zones in AP Vojvodina did not have at their disposal adeequate centraining center for their workers on the local level.

$\mathrm{Hb}_{05}$ : Most foreign investors that operate in the free investment zones in AP Vojvodina have at their disposal the services of scientific research institutions on a local level.

$\mathrm{Hb}_{15}$ : Most foreign investors that operate in the free investment zones in AP Vojvodina did not have at their disposal the services of scientific research institutions on a local level.

$\mathrm{Hb}_{06}$ : Most foreign investors that operate in the free investment zones in AP Vojvodina cooperated so far with some of the higher education institutions in the area of research and development activities.

$\mathrm{Hb}_{16}$ : Most foreign investors that operate in the free investment zones in AP Vojvodina did not cooperate so far with some of the higher education institutions in the area of research and development activities.

Note. Defined by the authors. 
66 I RESEARCH OF FOREIGN INVESTORS' OPINIONS ON THE QUALITY OF WORKFORCE EDUCATION AND PROFESSIONAL IMPROVEMENT IN THE AUTONOMOUS PROVINCE OF VOJVODINA

\section{DATA PROCESSING AND ANALYSIS}

The researched foreign investors that operate on the free investment zones of AP Vojvodina are mostly satisfied with the education quality in the Republic of Serbia. Their experiences so far with the workforce give the conclusion that the highest level of satisfaction is shown in the case of highly educated workforce and the education quality in the area of technical sciences. Furthermore, foreign investors believe that there is quality to a large degree in higher education in the area of mathematical sciences, and higher education in vocational schools.

Almost $30 \%$ of the examinees think that the education in the Republic of Serbia is characterized by a noticeably high level of quality, and around $40 \%$ think the quality level is very good. More than $70 \%$ of the questioned foreign investors think that the quality of higher education in the area of technical sciences is very good (50\%), that is, that its quality is excellent (22\%). Similar evaluation was given when the examinees were asked about the quality of higher education in the area of mathematical sciences. It can be noted that only the quality of higher education in these two areas none of the examinees evaluated as fair or poor. Almost $40 \%$ of the examinees are very satisfied with higher education quality in vocational schools, $28 \%$ evaluate it as very good, $22 \%$ think that this form of education is of average quality, and $11 \%$ state that the quality is of lower degree.

When evaluating the quality of higher education at the faculties and business vocational schools, foreign investors showed similar opinions. 39\% of the examinees believe that the quality of higher education in business vocational schools is very good, $33 \%$ state the same when it comes to the quality of higher education at the faculties. $27 \%$ of foreign investors show the average level of satisfaction with the education quality in business vocational schools, while in the case of evaluating the education quality at the faculties there was 39\% of average satisfaction. The equal number of examinees $(17 \%)$ state that quality of higher education in business vocational schools is excellent, that is, that it is fair. This ratio is somewhat different in evaluating the education quality in faculties, meaning that a higher number of examinees state that the quality of education is fair $(17 \%)$, while a smaller number of examinees is noticeably satisfied with the quality of this form of education $(11 \%)$. 
Quality of the education system in the Republic Serbia

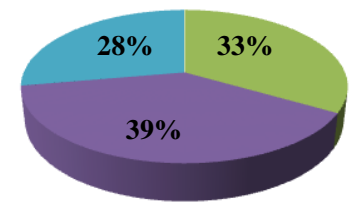

Quality of education in high schools

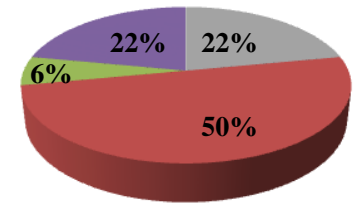

Quality of education in the field of mathematics (higher)

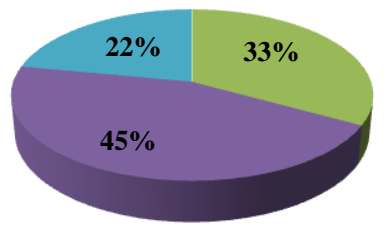

Quality of primary education

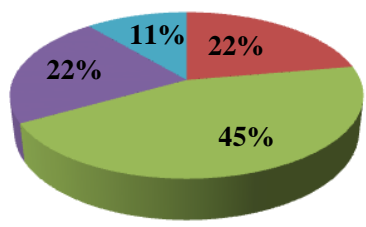

Quality of education in higher vocational schools

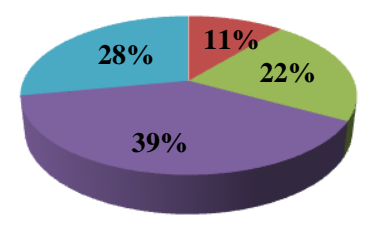

Quality of education in the field of technics (higher)

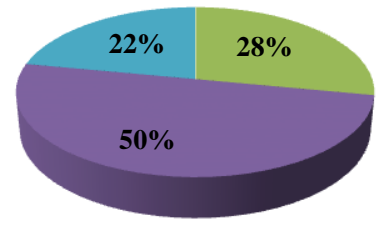

Quality of education in secondary vocat. schools (3)

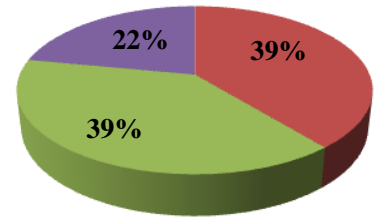

Quality of the education in faculties

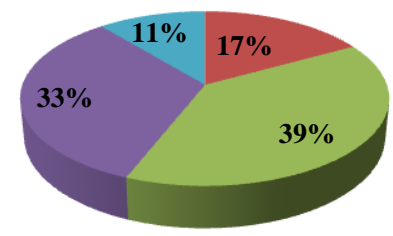

Quality of education in secondary vocat. schools (4)

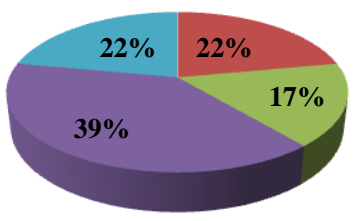

Quality of education in business schools (higher)

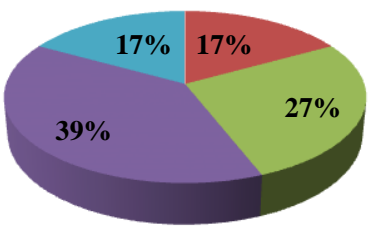

Figure 1. Structure of respondents' answers to questions about the quality of education. 
68 | RESEARCH OF FOREIGN INVESTORS' OPINIONS ON THE QUALITY OF WORKFORCE EDUCATION AND PROFESSIONAL IMPROVEMENT IN THE AUTONOMOUS PROVINCE OF VOJVODINA

Table 2

Descriptive statistics

\begin{tabular}{|c|c|c|c|c|c|c|c|c|c|c|c|c|c|}
\hline & క్ & 胥 & 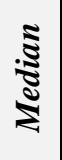 & 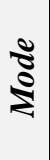 & 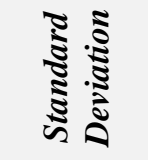 & : & 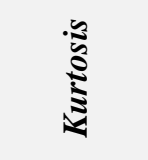 & 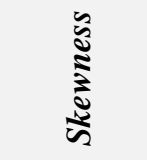 & 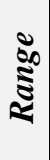 & 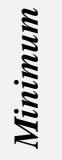 & 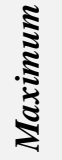 & $\underset{\mathbf{s}}{\$}$ & 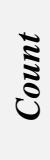 \\
\hline Q1 & 3,944444 & 0,189119 & 4 & 4 & 0,802366 & 0,643791 & $-1,39166$ & 0,105968 & 2 & 3 & 5 & 71 & 18 \\
\hline Q2 & 3,222222 & 0,222222 & 3 & 3 & 0,942809 & 0,888889 & $-0,38879$ & 0,45234 & 3 & 2 & 5 & 58 & 18 \\
\hline Q3 & 2,833333 & 0,18524 & 3 & 3 & 0,785905 & 0,617647 & $-1,24127$ & 0,318105 & 2 & 2 & 4 & 51 & 18 \\
\hline Q4 & 3,611111 & 0,257424 & 4 & 4 & 1,092159 & 1,19281 & $-1,11375$ & $-0,31921$ & 3 & 2 & 5 & 65 & 18 \\
\hline Q5 & 2,277778 & 0,253157 & 2 & 2 & 1,074055 & 1,153595 & $-0,7038$ & 0,655428 & 3 & 1 & 4 & 41 & 18 \\
\hline Q6 & 3,833333 & 0,23221 & 4 & 4 & 0,985184 & 0,970588 & $-0,60569$ & $-0,46138$ & 3 & 2 & 5 & 69 & 18 \\
\hline Q7 & 3,388889 & 0,216008 & 3 & 3 & 0,916444 & 0,839869 & $-0,56614$ & 0,110391 & 3 & 2 & 5 & 61 & 18 \\
\hline Q8 & 3,555556 & 0,231819 & 4 & 4 & 0,983524 & 0,96732 & $-0,80188$ & $-0,17347$ & 3 & 2 & 5 & 64 & 18 \\
\hline Q9 & 3,888889 & 0,178755 & 4 & 4 & 0,758395 & 0,575163 & $-1,11826$ & 0,194789 & 2 & 3 & 5 & 70 & 18 \\
\hline Q10 & 3,944444 & 0,170968 & 4 & 4 & 0,725358 & 0,526144 & $-0,90427$ & 0,085629 & 2 & 3 & 5 & 71 & 18 \\
\hline
\end{tabular}

Note. Calculated by the authors. 
When evaluating the education quality in secondary schools, foreign investors showed very different statements. More than $60 \%$ believe that the quality of education in secondary, vocational, and schools with 4 years duration is of high quality, with $39 \%$ saying that the quality was very good and $22 \%$ said it was excellent.

In the case of secondary vocational schools, 3 years duration, the equal number of foreign investors (39\%) believe that the quality of this form of education is good, or that it is fair. It is interesting that the rest of the examinees (22\%) believe that the quality of this education is very good and that they did not give it neither the highest nor the lowest marks.

The quality of education in high schools was evaluated the most poorly, not only within the group of questions related to secondary education, but also in all the questions related to the education quality in general. It is only in this situation that the examinees say they are very unsatisfied, with $22 \%$ believing that the education quality in high schools is poor. Even $50 \%$ of foreign investors state that the quality of this form of education is fair, and only $6 \%$ say that the quality is good. The average mark of the education quality in high schools is 2,28 (marks' range is from 1 to 5) when the statements of all the examined foreign investors are taken into account.

More than $30 \%$ of questioned foreign investors believe that the education quality in primary schools is very good $(22 \%)$, or that it is excellent $(11 \%)$, while $45 \%$ examinees evaluate it as good quality. The rest of the examinees (22\%) think that the quality of this form of education is fair.

During the researched year, foreign investors that operate in the free investment zones of AP Vojvodina gave special attention to additional, professional training of their workers (Figure 2). Almost $80 \%$ examinees gave their employees the opportunity to certaint professional development programs, while more than $60 \%$ organized certain professional/expert courses in their company. More than $70 \%$ of foreign investors gave the opportunity to the pupils and/or students to get the programs of professional training or appropriate training in their companies.

Questioned about the cooperation with local institutions that deal with expert/professional training, scientific research and development activities, $61 \%$ of foreign investors were for the possibility to satisfy the needs for the training of their workers through the cooperation with appropriate local centers. A little over half of the examinees (56\%) state that, locally, they have at their disposal the services of scientific research institutions, but that they still have not cooperated with some of the higher education institution in scientific research activities (83\%) 
Did any of your staff attend professional development courses in 2018 ?

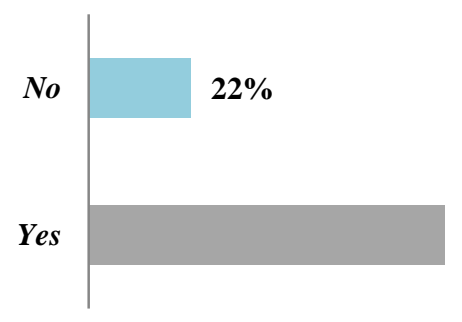

Did you accept students to internship or training programmes in 2018?

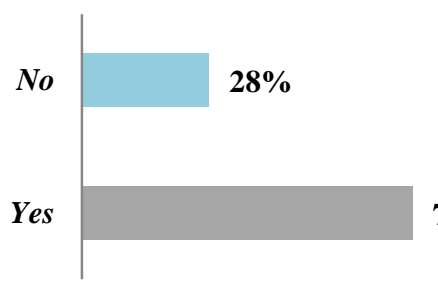

Have you got access to the services of scientific and research institutions at local level?

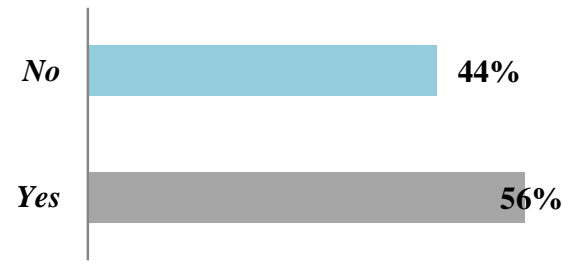

Did you organize any professional development course withing your company in 2018 ?

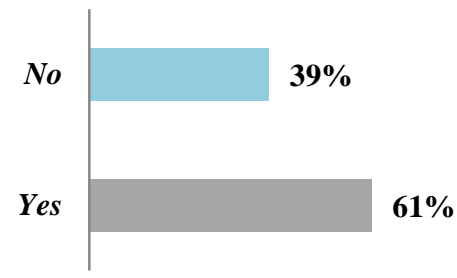

Are any of the adequate training centers available for your employees at local level?

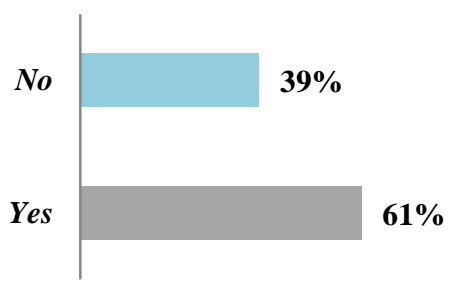

Have you collaborated with any of the higher education institutions in the field of research and development?

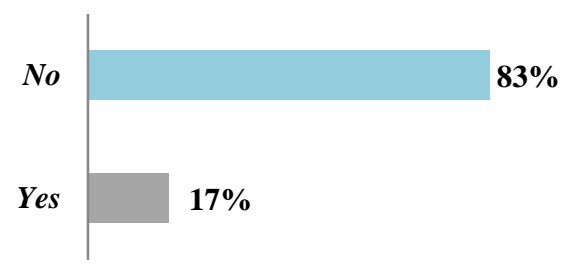

Figure 2. Structure of respondents' answers to questions about the quality of professional development and training Note. Calculated by the authros. 


\section{CONCLUDING REMARKS}

\subsection{RESEARCH CONCLUSIONS}

Foreign investors who operate in free investment zones in AP Vojvodina are satisfied with the quality of education and professional training of the workforce which shows the acceptance of the general, zero hypothesis (H0). When observing individual types of education, the examinees clearly stated opinions about the quality of those educations which further conditioned the acceptance or rejection of specific and individual research hypotheses.

In the case of the first group of specific research hypotheses, the zero hypothesis ( $\mathrm{HaO})$ is accepted and it is concluded that the majority of foreign investors who operate in the free investment zone in AP Vojvodina are satisfied with the education quality of the workforce.

The authors conclude that the majority of the foreign investors are satisfied with the quality of global education in the Republic of Serbia as a host country. One third of the questioned investors think that education quality in primary schools is at a high level, while more than $40 \%$ show the average satisfaction with the quality of this type of education. When it comes to secondary education, foreign investors are much more satisfied with the education quality in secondary vocational schools compared to high schools. A greater degree of satisfaction is present in the case of education quality in secondary, vocational schools with four years duration. Even $61 \%$ of the examinees evaluate it as having noticeable quality and having high education quality. The satisfaction degree with the education quality in secondary, vocational, three year duration schools is on a somewhat lower level. The half of almost $80 \%$ of the examinees think that this quality education is lower, while the other half evaluates it as being of average quality. In this case, not one foreign investor gave the highest mark related to the noticeably high quality level. Foreign investors are not satisfied with the education quality in high schools. Almost one fourth of the examinees think that the quality of this education is at the minimal level, while the half of the examinees note that they are satisfied with its quality to a lower degree.

Foreign investors that operate in the free investment zones of AP Vojvodina are very satisfied with the quality of higher education. The highest level of quality is recorded in the case of higher education in the area of technical sciences, and then in the area of mathematical sciences. More than half of the examinees also evaluates highly the quality of higher education in business vocational schools and think that the education in these institutions are at a high level (17\% of the examinees see it as being of noticeable quality). Observing the education quality in higher education vocational institutions (regardless of their orientation), it can be noted that almost one third of the examinees chooses noticeably high quality levels. Slightly lower 
72 I RESEARCH OF FOREIGN INVESTORS' OPINIONS ON THE QUALITY OF WORKFORCE EDUCATION AND PROFESSIONAL IMPROVEMENT IN THE AUTONOMOUS PROVINCE OF VOJVODINA

but still good mark was given to the higher education quality in faculties, and it can be concluded that he questioned foreign investors are also satisfied with the university education.

In the case of the second group of specific research hypotheses, the zero hypothesis is accepted $(\mathrm{HbO})$ and it is concluded that the majority of foreign investors that operate in the free investment zones of AP Vojvodina are satisfied by the level and quality of professional training of the workforce.

Majority of the questioned foreign investors provided the opportunity for their employees to attend different professional training programs. They also dealt with the internal organization and realization of professional courses. Near one third of the examinees gladly accepted the requests of pupils and/or students for having professional training in the companies of foreign investors. At the local level, most companies have at their disposal different centers for professional training of the workers and the services of scientific research institutions. However, for now, only a small number of foreign investors choose to cooperate with scientific institutions and the higher education institutions for scientific research activities.

\subsection{CONTRIBUTION OF THE RESEARCH AND KEY RECOMMENDATIONS}

The authors of this empirical study came to the certain research conclusions and they gave their scientific contribution by reaching new knowledge about the opinions of foreign investors that operate in the free investment zones in AP Vojvodina, that are related to the quality of education and professional training of the workforce. The scientific contribution of the results of this research is seen in the focus of the authors on the quality of all the areas of education: primary, secondary (vocational and high school) and high (university and vocational). Furthermore, this research set a certain general basis for doing future research that would deal in much greater detail with the satisfaction of foreign investors in AP Vojvodina with the quality of certain types of education, based on the experiences related to the engaged workforce.

Based on the empirical research, the authors single out certain recommendations that can have significant practical implications for the creators of the public policies, especially the policy of encouraging foreign investment, then for creators of the measures for the improvement of education on the territory of AP Vojvodina as well as for different institutions that deal with the realization of professional education and improvement programs.

The authors of the research recommend that it is necessary to create a more intensive connection between companies, foreing investors, who operate in 
the free zones of AP Vojvodina and educational institutions. The educational system has to be directed towards the increase of the number of qualified workers within the deficit professions, and also to increase the number of workers that would, when they get on the labor market, have the needed knowledge and competencies. Foreign investors should continue with the todate practice of motivating the employees to gain knowledge and experience that can later on be transferred to other companies owned by the same foreign investor. Within the cooperation of the companies and the educational institutions it is needed to gain additional theoretical knowledge of the workers by having practical experiences and to coordinate educational programs, not only in secondary vocational schools but also in higher education institutions, with the needs of the foreign companies.

In the future, the development of the cooperation between educational institutions and foreign companies through organizing professional training and thematic training programs surely should be encouraged. In that way the potential worker can prepare for the future engagement in the company. Moreover, the improvement of the cooperation would influence the creation of more attractive study programs and the programs of secondary vocational education which would contribute the enrichment of the competences of the graduate students and secondary school students with those knowledge and skills that are of great value for the foreign investors as employers.

The recommendation is to intensify the development of the cooperation between foreign investors in the free zones of AP Vojvodina and scientific research institutions and higher education institutions in exchanging knowledge,experience and the development of scientific research projects. In the future, besides the aforementioned, it is important to improve the application of the knowledge gained through all levels of education (primary, secondary and high) which will enrich the experience of future workers.

Considering that one of the goals of the economic growth of AP Vojvodina region deals with the intensifying FDI inflows, equal attention should be given to both passive and active measure in the implementation of the encouragement of foreign investment politics. Passive politics is tied to the emphasis on the competitive advantages of the host country, such as: the availability of the natural resources, the value of human resources and low costs of the workforce, geographical location etc. On the other hand, the measures of active politics would establish the continuity in inflows of higher FDI amount, meaning that a special attention must be given in establishing macroeconomic stability, liberalization of the economic movements and the improvement of the quality of infrastructure. 
74 | RESEARCH OF FOREIGN INVESTORS' OPINIONS ON THE QUALITY OF WORKFORCE EDUCATION AND PROFESSIONAL IMPROVEMENT IN THE AUTONOMOUS PROVINCE OF VOJVODINA

\section{REFERENCES}

Abbas, S., \& El Mosallamy, D. (2016). Determinants of FDI Flows to Developing Countries: An Empirical Study on the MENA Region. Journal of Finance and Economics, 4(1), 30-38.

Aghion, P., \& Howitt, P. (1998). Endogenous Growth Theory. Cambridge, MA: MIT Press

Agiomirgianakis, G., M., Asteriou, D., \& Papathoma, K. (2003). The determinants of foreign direct investment: a panel data study for the OECD countries (Report No. 03/06). London, UK: Department of Economics, City University London.

Akin, M. S., \& Vlad, V. (2011). The relationship between education and foreign direct investment: testing the inverse $U$ shape. European Journal of Economic and Political Studies, 4(1), 27-46.

Anastassopoulos, G. (2007). Countries' International Competitiveness and FDI: an empirical analysis of selected EU Member-Countries and Regions. Journal of Economics and Business, 10(1), 35-52.

Baez-Morales, A. (2014). A panel data analysis of FDI and informal labor markets. AQR-Working Papers, 14(02).

Barro, R. J., \& Lee, J. W. (2001). International data on educational attainment: updates and implications. oxford Economic papers, 53(3), 541-563.

Becker, S. O., \& Muendler, M. A. (2008). The effect of FDI on job security. The BE Journal of Economic Analysis \& Policy, 8(1).

Blomstrom, M., Lipsey, R. E., \& Zejan, M. (1992). What explains developing country growth? (No. w4132). National bureau of economic research.

Borensztein, E., De Gregorio, J., \& Lee, J. W. (1998). How does foreign direct investment affect economic growth?. Journal of international Economics, 45(1), 115-135.

Bosworth, B., \& Collins, S. (2003). The empirics of growth: An update. Brookings Papers on Economic Activity, 2, 113-206.

Chang, R., Kaltani, L., \& Loayza, N. (2009). Openness can be good for growth: The role of policy complementarities. Journal of Development Economics, 90(1), 33-49. 
Cheng, L. K., \& Kwan, Y. K. (2000). What are the determinants of the location of foreign direct investment? The Chinese experience. Journal of International Economics, 51(2), 379-400.

Driffield, N., \& Taylor, K. (2000). FDI and the labour market: a review of the evidence and policy implications. Oxford Review of Economic Policy, 16(3), 90-103.

Dunning, J., H. (1993). Multinational enterprises and the global economy. New York: Addison Wesley

Durham, B. (2004). Absorptive capacity and the effects of foreign direct investment and equity foreign portfolio investment on economic growth. European Economic Review, 48(2), 285-306.

Feenstra, R. C., \& Hanson, G. H. (1997). Foreign direct investment and relative wages: Evidence from Mexico's maquiladoras. Journal of International Economics, 42(3-4), 371-393

Gorbunova, Y., Infante, D., \& Smirnova, J. (2012). New evidence on FDI determinants: an appraisal over the transition period. Prague Economic Papers, 2, 129-149.

Hallward-Driemeier, M. (2003). Do Bilateral Investment Treaties Attract FDI?: Only a Bit... and They Could Bite. Washington, DC: World Bank, Development Research Group, Investment Climate.

Hanson, G. H. (1996). Economic integration, intraindustry trade, and frontier regions. European economic review, 40(3-5), 941-949.

Hanushek, E., \& Kimko, D. (2000). Schooling, labor-force quality, and the growth of nations. The American Economic Review, 90(5), 11841208 .

Hanushek, E. A., \& Wößmann, L. (2007). The role of education quality for economic growth. The World Bank.

Harms, P., \& Lutz, M. (2006). Aid, governance and private foreign investment: Some puzzling findings for the 1990s. Economic Journal, 116(513), 773-790.

Kinoshita, Y., \& Campos, N., F. (2002). The location determinants of foreign direct investment in transition economies. University of Michigan William Davidson Institute and CERP.

Lansbury, M., Pain, N., \& Smidkova, K. (1996). Foreign direct investment in Central Europe since 1990: an econometric study. National Institute Economic Review, 104-114. 
76 | RESEARCH OF FOREIGN INVESTORS' OPINIONS ON THE QUALITY OF WORKFORCE EDUCATION AND PROFESSIONAL IMPROVEMENT IN THE AUTONOMOUS PROVINCE OF VOJVODINA

Mahmood, I., Ehsanullah, M., \& Ahmed, H. (2011). Exchange rate volatility \& macroeconomic variables in Pakistan. Business Management Dynamics, 1(2), 11-22.

Miyamoto, K. (2003). Human capital formation and foreign direct investment in developing countries. Organisation for Economic Cooperation and Development (OECD) Paper, (211).

Narula, R., \& Wakelin, K. (1998). Technological competitiveness, trade and foreign direct investment. Structural Change and Economic Dynamics, 9(3), 373-387.

Noorbakhsh, F., Paloni, A., \& Youssef, A. (2001). Human capital and FDI inflows to developing countries: New empirical evidence. World Development, 29(9), 1593-1610.

Nunes, L., C., Oscátegui Arteta, J., A., \& Peschiera, J. (2006). Determinants of FDI in Latin America. Documentos de Trabajo/Working Papers from Department de Economia-Pontificia Universidad Catolica del Peru, No 2006/252.

Nunnenkamp, P. (2002). Determinants of FDI in developing countries: has globalization changed the rules of the game? Kiel Working Paper, No. 1122.

Nunnenkamp, P., \& Spatz, J. (2003). Intellectual Property Rights and Foreign Direct Investment: The Role of Industry and Host-Country Characteristics. Kiel Working Paper, No. 1167.

Nunnenkamp, P., \& Spatz, J. (2002). Determinants of FDI in developing countries: Has globalization changed the rules of the game? Transnational Corporations, 11(2), 1-34

Popovici, O. C., \& Calin, A. C. (2015). The Effects of Enhancing Competitiveness on FDI Inflows in CEE Countries. European Journal of Interdisciplinary Studies, 7(1), 55.

Pravakar, S. (2006). Foreign direct investment in South Asia: Policy, trends, impact and determinants. ADB Institute Discussion Papers, No. 56.

Ranjan, V., \& Agrawal, G. (2011). FDI Inflow Determinants in BRIC Countries: A Panel Data Analysis. International Business Research, $4(4), 255$.

Sadka, E., Razin, A., \& Rubinstein, Y. (2004). Which Countries Export FDI, and How Much?. In 2004 Meeting Papers (No. 226). Society for Economic Dynamics. 
Sakali, C. (2013). Determinants of Foreign Direct Investment (FDI) in Bulgaria: An econometric analysis using panel data. Journal of Economics and Business, 16(1), 73-97.

Schneider, F., \& Frey, B. (1985). Economic and Political Determinants of Foreign Direct Investment. World Development, 13(2), 161-175.

Slaughter, M. J. (2004). Skill upgrading in developing countries: Has inward foreign direct investment played a role?. In Labor and the Globalization of Production (pp. 121-145). Palgrave Macmillan, London.

Soumaré, I., \& Tchana Tchana, F. (2015). Causality between FDI and financial market development: evidence from emerging markets. The World Bank Economic Review, 29, 205-216.

Szanyi, M. (2003). An FDI-based development model for Hungary-new challenges? (No. 141). Institute for World Economics-Centre for Economic and Regional Studies-Hungarian Academy of Sciences.

Wang, M., \& Wong, M. C. S. (2009). FDI and economic growth: The growth accounting perspective. Economic Inquiry, 47(4), 701-710.

$\mathrm{Xu}$, B. (2000). Multinational enterprises, technology diffusion, and host country productivity growth. Journal of Development Economics, 62(2), 477-493.

Zhang, K. (2001). Does foreign direct investment promote economic growth? Evidence from East Asia and Latin America. Contemporary Economic Policy, 19(2), 175-185.

Zhang, K. H., \& Markusen, J. R. (1999). Vertical Multinationals and HostCountry Characteristics. Journal of Development Economics, 59(2), 233-252.

Note: This paper is a part of the research project "The analysis of foreign investors experiences in free zones related to the labour market in the Autonomous Province of Vojvodina" financed by the Provincial Secretariat for Higher Education and Scientific Research of Autonomous Province of Vojvodina, Republic of Serbia.

Project Number: 142-451-2736/2018-02-1. 